\title{
薄層RCプレキャスト版による オーバーレイエ法に関する研究
}

\author{
小梁川雅 ${ }^{1} \cdot$ 福田萬大 $^{2} \cdot$ 西澤辰男 $^{3}$ \\ ${ }^{1}$ 工博 東京農業大学講師 農学部農業工学科( \\ 大成口テック株式会社技術研究所 ( 365 鴻坚市大字上谷1456) \\ ${ }^{3}$ 工博 石川工業高等専門学校助教授 環境都市工学科 (
}

\begin{abstract}
薄層RCプレキャスト版オーバーレイ工法は，工場等で作製された比較的寸法の小さな薄首のRC版を施工 箇所まで運搬し，並へて表層舗装を構筑するもので，アスファルト赤装の維持修繒工法として有効である と考えられる。しかし薄首RC版の力学的特性に関しては十分に明らかとなっていない．本研究では，実物 大の薄層RCプレキャスト版を用いた載荷試験を行い，その力学的特性を明らかとした。この載荷試験の結 果より，薄層RCプレキャスト版の耐荷力を確認した。この結果を受けて，重交通の工場ヤード戟装にこの 舗装を施工し，その供用性能を検証した。
\end{abstract}

Key Words : concrete pavement, precast pavement, overlay

\section{1.はじめに}

プレキャストコンクリート舗装は, 予め工場等で 作製しておいたコンクリート版を施工箇所まで運搬 して舗設する工法である。この工法では，コンクリ 一トの製造，養生等が十分な管理の下で行えること から, 安定した品質・強度を有するコンクリート版 を一度に多数供給できる。またその舗設にあたって は, 特殊施工機械が必要がない，さらに舗設時間が 比較的短く, 舗設直後の交通開放が可能であること 等が大きな長所となっている.

都市内道路のアスファルト舗装区間では，わだち 掘れなどによる舗装破損が多く発生しており，これ らの維持修繥が今後増大すると予想される. 都市内 道路では工事期間の短縮や交通確保が問題となるが, 施工の省力化・効率化の観点からプレキャスト舗装 は有効であると考えられる。また耐久性の高いコン クリートを用いることによって, 維持修繥頻度およ び費用の低減をはかることができる.

この様にプレキャストコンクリート舗装は大きな 利点を有してはいるが, 一方で, 舗設時のコンクリ 一ト版の運搬・設置の面から考えると，その重量お よび寸法には制約がある，通常の無筋コンクリート によってプレキャスト版を作製する場合，十分な耐
荷力を得るためには版厚を減少させることが難しく， 必然的に版の寸法を小さくせざるを得ない. しかし， 版の寸法を小さくした場合には目地が増加すること となり，施工の面から見れば手間が多くなり，また 施工後の乗り心地の面からも好ましくない，従って 版厚を薄くし, 版の大きさをある程度確保すること が望ましい，そこで本研究では，100mmの薄層コン クリート版の検封を行うこととした。

無筋コンクリート版の版厚を100mmとした場合に は, 十分な耐荷力を得るためにはコンクリートの曲 げ強度として $10 \mathrm{~N} / \mathrm{mm}^{2}$ 以上が要求される。筆者らは この様な高曲げ強度コンクリートに関する検討 ${ }^{1)}$ 行ったが, 安定して高曲げ強度を得ることはかなり 困難であることがわかった。そこで本研究では薄層 の鉄筋コンクリート版を用いることとし，その耐荷 力の検討および, 実物大のRCプレキャストコンクリ 一ト版による試験舗装を実施した。

\section{RCプレキャスト版の設計}

本研究では前述の通り, $\mathrm{RC}$ プレキャスト版の版厚 を $100 \mathrm{~mm}$ とることとした．以下でこのRCプレキャ スト版の設計を行ってみた。 
(1)RCプレキャスト版

計算対象としたRCプレキャスト版は，長さ5m，幅 $1.75 \mathrm{~m}$, 版厚 $100 \mathrm{~mm}$ である. プレキャスト版は特殊ジ ヨイントで接合され, 目地における荷重伝達効果は 考慮しない．鉄筋としてはSD345の異形鉄筋D13を用 い,コンクリート版底面から $30 \mathrm{~mm}$ の位置に $100 \mathrm{~mm}$ 間 隔に配筋することとした。

\section{(2)RCプレキャスト版の発生応力}

設計条件は以下に示すとおりである。

コンクリート版厚 : $100 \mathrm{~mm}$

コンクリート压縮強度 : $25 \mathrm{~N} / \mathrm{mm}^{2}$

コンクリートの弾性係数: $25 \mathrm{kN} / \mathrm{mm}^{2}$

コンクリートのポアソン比 : 0.2

コンクリートの温度膨張係数 : 0.00001

路盤支持力係数 $\mathrm{K}_{75}: 0.15 \mathrm{~N} / \mathrm{mm}^{3}$

タイヤの接地圧 : $0.63 \mathrm{~N} / \mathrm{mm}^{2}$

計算位置：縦自由縁部

交通量としてはD交通対応を考虑し，セメントコン クリート舖装要綱 ${ }^{2}$ 付録に示される輪荷重分布を用 いた。輪荷重分布および温度頻度は表-1に示すとお りである.

以上の条件より，コンクリート標準示方書「舗装 編」 ${ }^{3)}$ に示される手順に従って, コンクリート版に 発生する曲げ応力を算定した. その結果, このコン クリート版に発生する最大輪荷重および最大温度応 力はそれぞれ

$$
\begin{aligned}
& \sigma_{\mathrm{emax}}=8.034 \mathrm{~N} / \mathrm{mm}^{2} \\
& \sigma_{\mathrm{tmax}}=1.060 \mathrm{~N} / \mathrm{mm}^{2}
\end{aligned}
$$

となり,コンクリート版に作用する最大合成曲げ応 力は,

$$
\sigma_{\text {max }}=9.094 \mathrm{~N} / \mathrm{mm}^{2}
$$

となった.

\section{（3）限界状態に対する照査}

\begin{tabular}{|c|c|c|c|}
\hline \multicolumn{2}{|c|}{ 輪 荷重分布 } & \multicolumn{2}{|c|}{ 温度分布 } \\
\hline 輪荷重 $(\mathrm{kN})$ & 頻度 & 温度差 & 頻度 \\
\hline 10 & 14007 & 17 & 0 \\
\hline 20 & 1670 & 15 & 0 \\
\hline 30 & 922 & 13 & 0.004 \\
\hline 40 & 348 & 11 & 0.02 \\
\hline 50 & 191 & 9 & 0.05 \\
\hline 60 & 139 & 7 & 0.1 \\
\hline 70 & 70 & 5 & 0.135 \\
\hline 80 & 35 & 3 & 0.19 \\
\hline 90 & 17 & 1 & 0.5 \\
\hline 100 & 3 & -1 & 0.65 \\
\hline 110 & 0 & -3 & 0.35 \\
\hline 120 & 0 & -5 & 0 \\
\hline
\end{tabular}

最初に, このRCプレキャスト版の終局限界状態に

表-1 輪荷重分および温度頻度
対する照查を行う。ここでは，版厚および鉄筋間隔 がそれぞれ100mmであることから，RC版を100×100 mmの断面を持つ梁に置き換えて考える. 前項で求め られた最大合成曲げ応力より，この梁に作用する最 大曲げモーメントは,

$\mathrm{M}_{\max }=1.516 \mathrm{kN} \cdot \mathrm{m}$

となるコンクリートの材料係数を, 1.3 とている.

一方，与えられたコンクリート断面および鉄筋条 件からこのRC梁の鉄筋比および釣り合い鉄筋比を求 めるとそれぞれ，

$$
\mathrm{p}=0.0199
$$$$
\mathrm{p}_{\mathrm{b}}=0.0329
$$

となり，曲げ引張破壊を生じることがわかる．

次に終局破壊モーメントを求めると,

$\mathrm{Mud}_{\mathrm{d}}=2.314 \mathrm{kN} \cdot \mathrm{m}$

となる，従って終局限界状態に対する照査を満足す ることとなる.

次にひび割れ幅に対する照査を行う。ひび割れ幅 の限界状態に対しては，ひび割れ間隔と鉄筋最大応 力より求められるひび割れ幅と, 許容ひび割れ幅と の比較により照査する。ここで許容ひび割れ幅は, 一般の使用状態に対して0.15m的とれている3).一 方, 最大モーメントより求められたひび割れ幅は,

$0.144 \mathrm{~mm}$ となり満足される.

最後に疲労限界状態に対する照查を行った。ここ では設計寿命を 20 年とし，コンクリートの圧縮疲労 および鉄筋の引張疲労に対する照査を行った，その 結果コンクリートおよび鉄筋それぞれの疲労值は,

$\mathrm{FD}_{\mathrm{c}}=0.0002$

$\mathrm{FD}_{\mathrm{s}}=0.0152$

となり，疲労破壊を生じないこととなった。なおコ

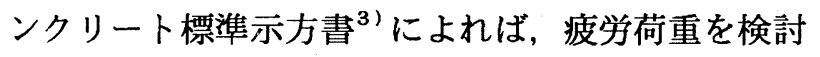
する場合, 永久荷重もしくは自重による荷重を最小 荷重として考慮することとなっているが, 舗装版の 場合には弾性支承上にあるためこれらを無視し, 最 小荷重は0であるとして計算している.

以上のように，ここで仮定したRCプレキャスト版 はD交通相当の交通量に対して, 設計寿命20年で破 壊しない結果となった。

\section{3・実物大RCプレキャスト版による載荷試験}

本研究では, 版厚100mmの薄層プレキャストコン クリート舗装版を実際に作製し，実物大載荷試験を 行った。プレキャスト版の作製は大成ロテック株式 会社(以下大成ロテック)技術研究所で行い, 同研究 所構内に舗設して載荷試験を行った。 
表-2 配合表

\begin{tabular}{|c|c|c|c|c|c|c|c|c|c|c|c|}
\hline \multicolumn{12}{|c|}{ A配合 } \\
\hline \multirow{3}{*}{$\begin{array}{c}\text { 水結合 } \\
\text { 忉比 } \\
(\%) \\
\end{array}$} & \multirow{3}{*}{$\begin{array}{c}\text { 細骨 } \\
\text { 材率 } \\
(\%)\end{array}$} & \multirow[b]{3}{*}{$(\%)$} & \multirow[b]{3}{*}{ (kg) } & \multicolumn{5}{|c|}{ 単位量 } & \multicolumn{3}{|c|}{$\left(\mathrm{kg} / \mathrm{m}^{3}\right)$} \\
\hline & & & & 水 & セメン & 細骨材 & 粗骨材 & $\mathrm{G}$ & 鋼繊綡 & 漲材 & 混和剂 \\
\hline & & & & W & $\mathrm{C}$ & $\mathrm{S}$ & $20-13$ & $13-5$ & SF & $\mathrm{F}$ & 减水剂 $\mathrm{AE}$ 剂 \\
\hline 27.5 & 38.0 & - & - & 160 & 582 & 606 & 415 & 620 & - & - & \begin{tabular}{|l|l|}
10.6 & 0.175 \\
\end{tabular} \\
\hline
\end{tabular}

\begin{tabular}{|c|c|c|c|c|c|c|c|c|c|c|c|}
\hline \multicolumn{12}{|c|}{ B配合 } \\
\hline \multirow{3}{*}{$\begin{array}{l}\text { 水結合 } \\
\text { 材比 } \\
(\%)\end{array}$} & \multirow{3}{*}{$\begin{array}{c}\text { 細骨 } \\
\text { 材率 } \\
(\%)\end{array}$} & \multicolumn{2}{|c|}{ 鋼繊維膨張材 } & \multicolumn{5}{|c|}{ 単位量 } & \multicolumn{3}{|c|}{$\left(\mathrm{kg} / \mathrm{m}^{3}\right)$} \\
\hline & & & & 水 & セメン & 細骨材 & 粗骨材 & $\mathrm{G}$ & 鋼 繊糸 & 彭張材 & 混和剂 \\
\hline & & $(\%)$ & $(\mathrm{kg})$ & $\mathrm{W}$ & $\mathrm{C}$ & $\mathrm{S}$ & $20-13$ & $13-5$ & SF & $\mathrm{F}$ & 減水剂 $\mathrm{AE}$ 剂 \\
\hline 27.5 & 38.0 & - & 70 & 160 & 512 & 606 & 415 & 620 & - & 70 & \begin{tabular}{|l|l|}
10.6 & 0.175 \\
\end{tabular} \\
\hline
\end{tabular}

\begin{tabular}{|c|c|c|c|c|c|c|c|c|c|c|c|}
\hline \multicolumn{12}{|c|}{ C配合 } \\
\hline \multirow{3}{*}{$\begin{array}{c}\text { 水結合 } \\
\text { 材比 } \\
(\%)\end{array}$} & \multirow{3}{*}{$\begin{array}{c}\text { 細骨 } \\
\text { 材率 } \\
(\%)\end{array}$} & \multirow[b]{3}{*}{$(\%)$} & 影張材 & \multicolumn{5}{|c|}{ 単位量 } & \multicolumn{3}{|c|}{$\left(\mathrm{kg} / \mathrm{m}^{2}\right)$} \\
\hline & & & \multirow[b]{2}{*}{ (kg) } & 水 & セメン & 田骨材 & 粗骨材 & $\mathrm{G}$ & 鋼繊維 & 涱材 & 混和剤 \\
\hline & & & & $\mathrm{W}$ & $\mathrm{C}$ & $\mathrm{S}$ & $20-13$ & $3-5$ & SF & $\mathrm{F}$ & 减水剂 $\mathrm{AE}$ 剂 \\
\hline 32.5 & 55.0 & 1.0 & - & 175 & 538 & 860 & 296 & 442 & 80 & - & \begin{tabular}{l|l|l|}
13.5 & 0.081 \\
\end{tabular} \\
\hline
\end{tabular}

\section{(1)コンクリートの配合}

プレキャスト版の作製にあたっては，コンクリー トの高曲げ強度化も合わせて検討したため, 以下の 3種類のコンクリートを用いることとした。

A配合：高性能AE減水剂を用いてW/Cを低減したコン

$$
\text { クリート }
$$

B配合：高性能AE減水剤十膨張材を用いてケミカル プレストレストを導入したコンクリート

C配合 : 高性能AE減水剤十鋼繊維を用いたコンクリ -

表-2に配合表を示す。

これらの配合によるコンクリートの曲げ強度は， 供試体による材跉28日室内試験の結果, A配合が6.3 $8 \mathrm{~N} / \mathrm{mm}^{2}$ ， B配合が $8.59 \mathrm{~N} / \mathrm{mm}^{2}$, C配合が $14.33 \mathrm{~N} / \mathrm{mm}^{2}$ と なった。この結果, 鋼繊維補強コンクリートが最も 高い曲げ強度を示しているが，供試体間のばらつき も最も大きな結果を示し, 安定した曲げ強度を得る ことが難しいことがわかった。また材䠲90日の曲げ 強度で比較すると, 最も高い曲げ強度を示したのは, 膨張材を用いたコンクリートであった。

\section{(2)舖装構造}

載荷試験では上記 3 種類のコンクリートにより， 2 種類の大きさの版を作製し, 図一1の様に配置した. 載荷位置は, 自由縁部, 目地縁部, 隅角部, 中央部 とし，荷重とひずみ，たわみの関係を測定した。

図一に舗装断面を示す。プレキャストコンクリート 版舗設位置における路盤支持力係数 $\left(\mathrm{k}_{30}\right)$ を実測し た結果(15点), その平均值は $0.337 \mathrm{~N} / \mathrm{mm}^{3}$ であった. またそれぞれの配合によるコンクリートの載荷時に おける供試体曲げ強度は，A，B，C配合それぞれ $6.86 \mathrm{~N} / \mathrm{mm}^{2}, 13.54 \mathrm{~N} / \mathrm{mm}^{2}$ (鉄筋入り供試体による),

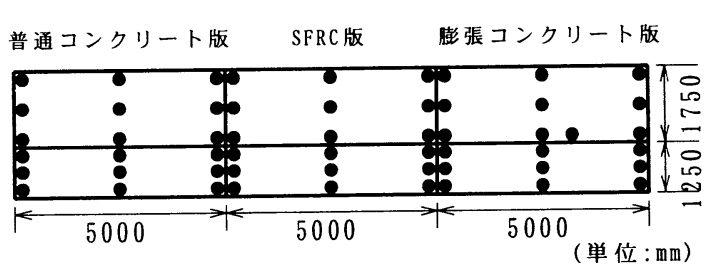

図-1 プレキャスト版配置並びに載荷位置(黒丸)

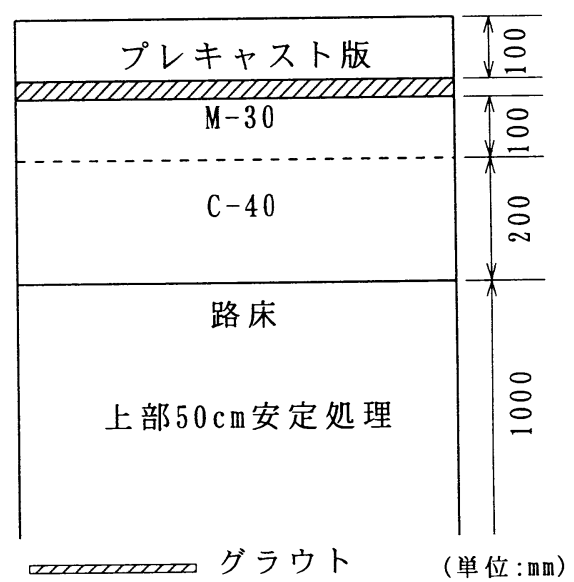

図-2 舗装断面

$12.09 \mathrm{~N} / \mathrm{mm}^{2}$ となった.

\section{（3）載荷試験結果}

図-3に示すのは, 膨張コンクリート版横自由縁部 に載荷した場合のコンクリート版表面の荷重一ひず み関係である。この図によれば，載荷点から版央方 向に離れたコンクリート版表面に引張応力が作用し ていることがわかる．荷重点から $900 \mathrm{~mm}$ の位置のひ ずみ変化によれば，約80kNでコンクリート版表面に ひびわれが発生したことが推察される。これよりコ 


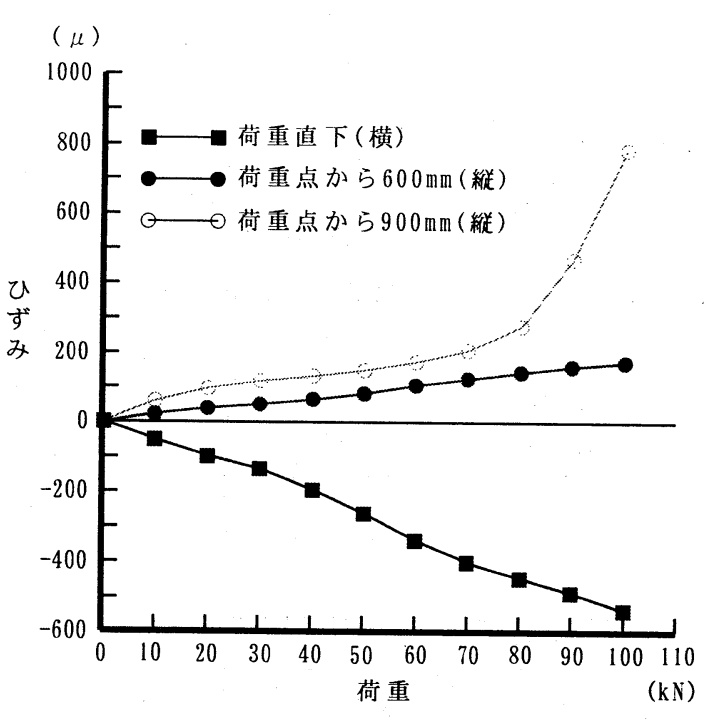

図-3 荷重一ひずみ関係

ンクリートの引張強度を推定すると約 $8.83 \mathrm{~N} / \mathrm{mm}^{2}$ と なり，供試体強度を若干下回っていた，以上のよう に,この様な薄層コンクリート版では, ひび割れが 版下面ばかりでなく, 載荷点から離れた版上面にも 発生する可能性があることがわかった。

本試験では, 上記プレキャスト版とは別に $5 \times 1.2$ 5mのプレキャスト版を作製し, 温度変化および湿度 変化に伴う長さ変化量およびそり変形量の測定も行 った . 図-4に測定用プレキャスト版寸法, 温度お よび変位測定位置を示す．測定は作製後約6力月を 経過したプレキャスト版によって行い，14日間の散 水の後乾燥させた.

長さ方向の変位の測定結果によると, 散水期間に おいては膨張し，乾燥期間では収縮を示した。この 変位を温度変化によるものと乾燥收縮によるものと に分離したところ, 温度変化に伴う版長方向の変位 は，乾燥期間においても若干の膨張を示していたが， 乾燥收縮に伴う収縮が大きく生じていることがわか った．乾燥期間における版長変化は，温度変化によ ると推定されるものが乾燥開始後約 1 力月で $0.6 \mathrm{~mm}$ 程 度の膨張を示したのに対して, 乾燥収縮のみによる と推定されるものは約 $0.7 \mathrm{~mm}$ の収縮を示しており，

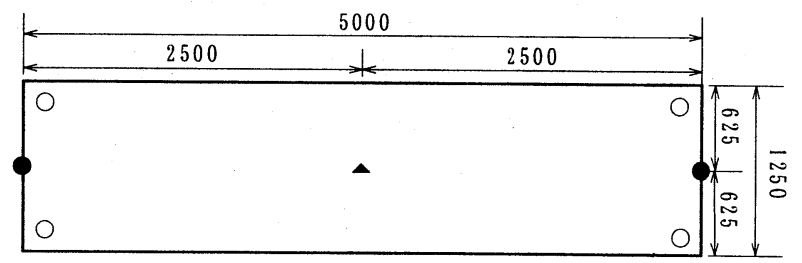

- 熱電対 - 軸方向変位測定位置 ○そり変位測定位直

図-4 変位測定用プレキャスト版 全体として0.1mm程度の収縮となった.

一方そり変位量によると乾燥1力月で, 最大約 1.5 $\mathrm{mm}$ 下に凸となる変形を示した。この期間の版内の温 度差はほぼ2〜 $8^{\circ} \mathrm{C}$ の範囲にあり, 温度変化によるそ り変形はわずかであり,そり変形のほとんどが乾燥 収縮によって生じていることがわかる.

その結果この様な薄層コンクリート版の場合，コ ンクリート版内の温度変化ばかりでなく，コンクリ 一トの乾燥収縮がコンクリート版の長さ変化および そり変形に大きな影響を及ぼすことが明らかとなっ た.

\section{4・RCプレキャスト版の供用試験}

実物大 $R C$ プレキャスト版の載荷試験により得られ た結果を基に，実際の交通荷重による供用試験を行 うこととした．舗設箇所は大成ロテック浦和合材工 場内のアスファルト舗装区間とし，1995年9月に施 工した．本工場では合材および材料搬入・搬出のた めのダンプトラックが, 一日約 1000 台通行しており, かなりの重交通箇所となっている。

\section{(1)RCプレキャスト版}

実物大載荷試験の結果, 載荷点から離れた RC版上 面にも引張応力が発生することがわかったので，供 用試験にあたってはこの点を考慮し，配筋を変える こととした.すなわち実物大載荷試験用プレキャス ト版では，鉄筋としてD13をコンクリート断面中央 に配置していたが，供用試験においては複鉄筋構造 とし，コンクリート版上面の引張応力に対しても対 処することとした．図-5にプレキャスト版の配筋の 一例を示す。

供用試験に用いたプレキャスト版は，図-5に示し た複鉄筋の配笳に表-2に示される配合のうちA配合 およびB配合のコンクリートを用いて作製した 2 種類 と，比較のために単鉄筋の配筋にB配合のコンクリ ートで作製したものを加えた 3 種類とした。 またプ レキャスト版の寸法は図-1に示される2種類とした ため, 合計6種類のプレキャスト版を作製し，舗設 した. プレキャスト版の作製は大成ロテック技術研 究所で行い, 養生後10tトラックにて運搬した。

\section{(2)プレキャスト版設置}

設置個所は，排水経路およびグラウト厚を考慮し， 既設路面の縦横断勾配を測量した上で決定した。プ レキャスト版の設置は, 20tクレーンを用いて行っ た. なお設置にあたっては, 施工後の平坦性を確保 するために, 各プレキャスト版の高さ調整を行った。 


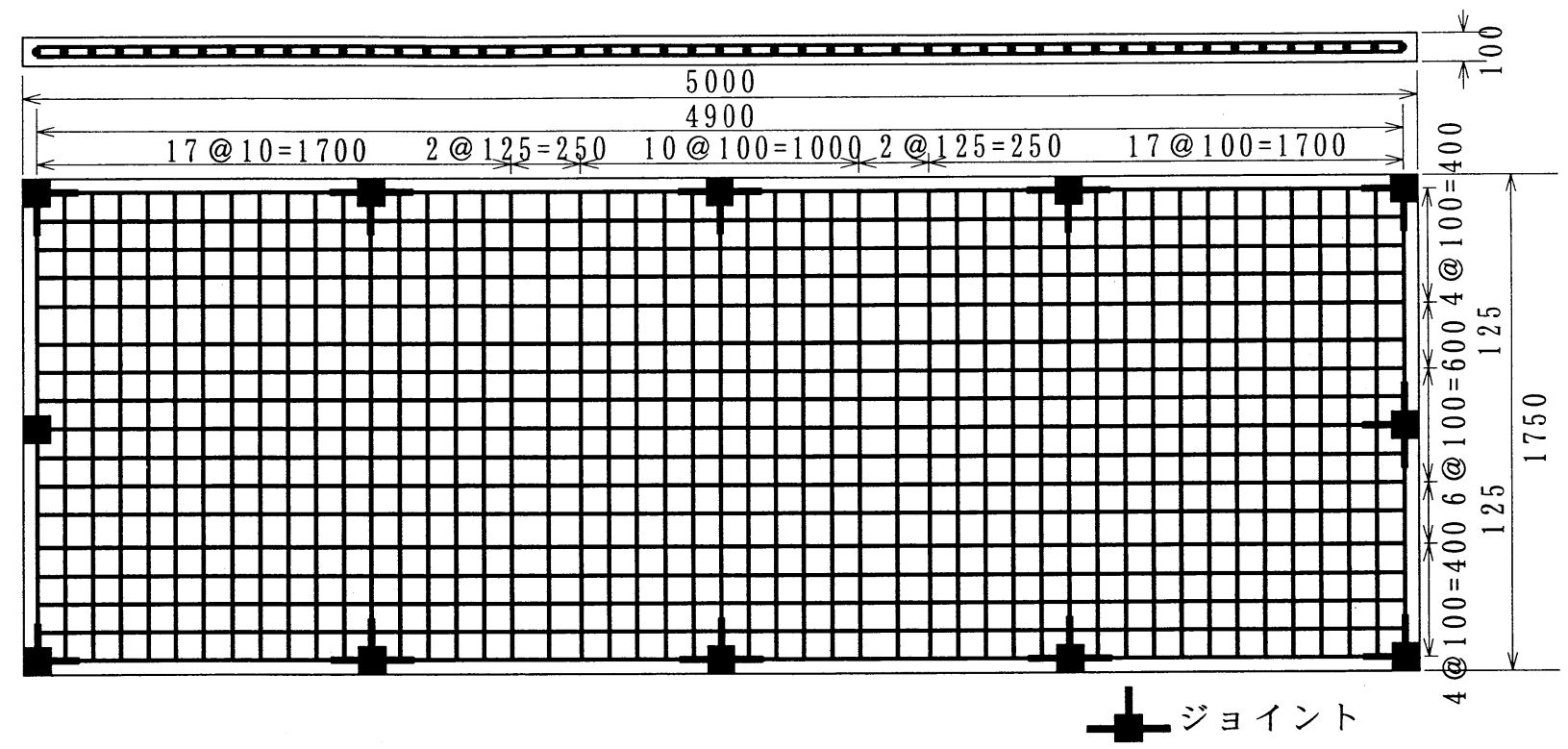

図-5 RCプレキャスト版の配筋

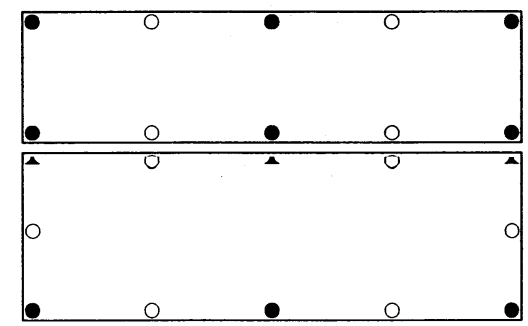

○グラウト注入孔

・高さ調整ボルト穴

・高さ調整ボルト穴兼グラウト注入孔

図-6高さ調整ボルト穴およびグラウト注入孔位置

これは，図-6に示す高さ調整ボルト穴にセットされ たボルトを調整することにより，プレキャスト版接 地後行った.

プレキャスト版の連結は，専用のジョイントを用 いて行った. ジョイントはコンクリート版作製時に, 図-5に示す位置に予め埋設されている。これにボル トをセットし, 高さ調整後, 専用工具により締め付 けた。なおプレキャスト版連結位置は，実物大載荷 試験および変位量測定結果を考慮して決定した。

\section{(3)グラウト注入}

高さ調整およびジョイント締め付け後, プレキャ スト版にグラウトの注入を行った. グラウトは施工 場所においてグラウトミキサによって混合し，専用 注入機を用いて図-6に示すグラウト注入孔より注入 した．注入は勾配の低い箇所から順に行った。グラ ウト厚は15m瞟としたが，既設舗装の不陸によ り平均 $18 \mathrm{~mm}$ 程度となった。
なお高さ調整ボルトは, グラウト硬化後取り去り， ジョイントに充填モルタルを打設した。

\section{（4）供用状況}

写真-1に供用現況を示す． RCプレキャスト版は施 工後約 1 年を経過しているが, 荷重に伴うひび割れ は発生しておらず，良好な供用状態を保持している. 縦目地，横目地部においても段差の発生は見られず, 目地部の角欠け等も発生していない。しかしながら 写真にも見られるように, ジョイント部において充 填モルタルにひび割れが発生しており，このひび割 れ部から充填モルタルの剥離が一部発生している. このジョイント部の充填に関しては, 今後の検討課 題であると考えられる.

\section{$5 \cdot$ 結論}

本研究では，薄層RCプレキャスト版によるオーバ ーレイ工法に関して検討を行った，得られた主な結 果をまとめると以下の通りである.

(1)版厚100mmのRC版に関して応力解析を行ったとこ ろ, D交通相当の交通量に対して破壊を生じない こと，またひび割れ幅も許容值以下であること が確かめられた。

(2)RCプレキャスト版の実物大載荷試験を実施し， 荷重応答特性, ひび割れの発生状況に関して検 討した。その結果，載荷点から離れた版上面に 引張応力が発生し，これにより版上面からのひ び割れが発生する可能性があることがわかった。 したがってRCプレキャスト版の配筋は，複鉄筋 

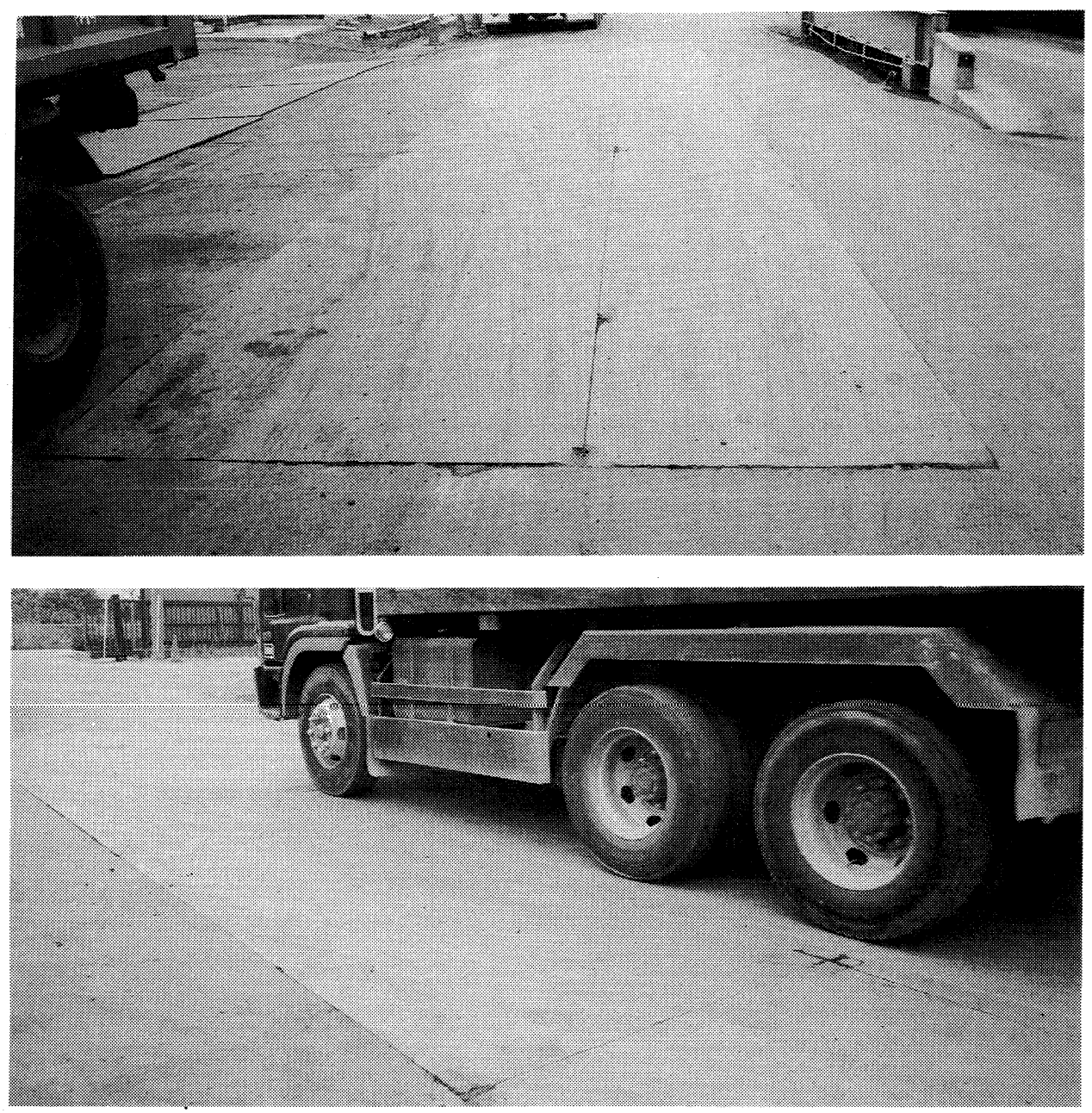

写真-1ＲCプレキャスト版の供用状況

とすることが望ましいことがわかった．

（3）RCプレキャスト版を重交通区間に舗設し，その 供用状況を検討した．供用 1 年後においてもひび 割れ，目地部段差は生じておらず，良好な供用 成績を示していることが明らかとなった。

(4)以上より, 薄層RCプレキャスト版によるオーバ ーレイ工法は，十分な供用性を期待できること が判明した。

\section{参考文献}

1）小梁川雅，西澤辰男，福田萬大：薄層プレキャスト舗 装に関する基礎的研究, 第21回日本道路会議論文集, pp. 1995

2）セメントコンクリート舗装要綱，日本道路協会，1984

3）コンクリート標準示方書「舗装編」, 土木学会, 1996

4) 越川喜孝, 伊藤文隆, 吉野康啓, 福田萬大: 薄層プレ キャストコンクリート舗装版の変形に関する実験, 土 木学会第51回年次学術講演会講演概要集 V, pp.58-59, 1996

\title{
A STUDY ON THE OVERLAY METHOD BY THIN PRECAST REINFORCED CONCRETE SLAB
}

\author{
Masashi KOYANAGAWA, Takatomo FUKUDA, Tatsuo NISHIZAWA
}

The thin reinforced concrete precast slab overlay method is the new effective rehabilitation method for asphalt concrete pavements. In this method, the small thin RC slabs are made at a yard, and then they are carryed and set on the asphalt concrete pavement. But the mechanistic properties of thin RC slabs are not clear enough. In this study, we investigate the mechanistic properties of slabs by the loading test of the real size slabs. From the results of the test, the RC slab have a enough ability for heavy loads. Then we constructed this thin RC precasted pavement for the heavy truffic road and examined the serveciability of this pavement. 